\title{
PENGARUH KOMPETENSI DAN INDEPENDENSI AUDITOR TERHADAP KUALITAS AUDIT: STUDI KASUS KANTOR AKUNTAN PUBLIK DI KOTA MAKASSAR
}

\author{
Muhammad Awal Ramadhan \\ Prodi Akuntansi, Universitas Muhammadiyah Palopo \\ muh.awalakt@gmail.com
}

\begin{abstract}
ABSTRAK
Penelitian ini bertujuan untuk mengetahui pengaruh kompetensi dan independensi auditor terhadap kualitas audit. Penelitian ini menggunakan auditor sebagai objek penelitian. Data yang digunakan adalah dataprimer berupa kuesioner yang dibagikan kepada auditor yang bekerja pada Kantor Akuntan Publik di Kota Makassar. Kuesioner yang dibagikan kepada responden sebanyak 37 dan kuesioner yang dikembalikan sebanyak 35. Penelitian ini menggunakan pendekatan kuantitatif dan menggunakan analisis regresi linier berganda dengan tambahan uji validitas daan uji reliabilitas. Penelitian ini juga menggunakan pengujian hipotesis berupa uji statisti t dan uji koefisien determinasi. Hasil penelitian ini menunjukkan bahwa kompetensi dan independensi auditor berpengaruh signifikan terhadap kualitas audit.
\end{abstract}

Kata kunci: Kompetensi, Independensi, Kualitas audit

\section{ABSTRACT}

This study aims to determine the effect of competence and auditor independence on audit quality. This study uses the auditor as the object of research. The data used are primary data sheets in the form of questionnaires distributed to auditors who work at the Public Accountant Office in Makassar City. Questionnaires were distributed to respondents as many as 37 and returned questionnaires as many as 35. This study uses a quantitative approach and uses multiple linear regression analysis with additional validity and reliability testing. This research also uses hypothesis testing in the form of a statistical test $t$ and the coefficient of determination test. The results of this study indicate that auditor competency and independence significantly influence audit quality.

Keywords: Competence, Independence, Audit quality

\section{PENDAHULUAN}

Laporan keuangan menyediakan berbagai informasi keuangan yang bersifat kuantitatif dan diperlukan sebagai sarana pengambilan keputusan baik oleh pihak internal maupun pihak eksternal perusahaan. Menurut FASB, ada dua karakteristik terpenting yang harus ada dalam laporan keuangan yakni relevan (relevance) dan dapat diandalkan (reliable). Kedua karakteristik tersebut sangatlah sulit untuk diatur, sehingga para pemakai informasi membutuhkan jasa pihak ketiga yaitu auditor independen untuk memberi jaminan bahwa laporan keuangan tersebut memang relevan dan dapat diandalkan serta dapat meningkatkan kepercayaan semua pihak yang berkepentingan dengan perusahaan tersebut. Singgih dan Bawono (2010) dalam Tjun Tjun (2012).

Akuntan publik adalah suatu profesi yang tugasnya melakukan audit atas laporan keuangan yang diterbitkan oleh suatu perusahaan (Haryono 2001:18). Profesi akuntan publik mempunyai tugas untuk menaikkan keandalan laporan keuangan, sehingga para pengguna 
laporan keuangan memperoleh informasi yang benar mengenai laporan keuangan yang diterbitkan oleh perusahaan.

Menurut De Angelo dalam Tjun Tjun (2012) mendefinisikan kualitas audit sebagai probability dimana seseorang auditor akan menemukan dan melaporkan pelanggaran yang ada dalam system akuntansi kliennya. Kemungkinan dimana auditor akan menemukan salah saji tergantung pada kualitas pemahaman auditor(kompetensi) sementara tindakan melaporkan salah saji tergantung pada independensi auditor.

Sementara itu American Accaounting Association's Financial Accounting Standard Commite (2000) dalam Christiawan (2003) menyatakan bahwa kualitas audit ditentukan oleh dua hal yaitu kompetensi dan independensi. Kedua hal tersebut berpengaruh langsung terhadap kualitas audit. Kualitas pemegang saham yang menaruh harapan tinggi bahwa laporan keuangan yang telah diaudit oleh KAP tentunya merupakan laporan keuangan yang bebas dari salah saji material, baik yang disebabkan oleh kekeliruan atau kecurangan. Kualitas audit ini penting karena dengan kualitas audit yang tinggi maka akan dihasilkan laporan keuangan yang dapat dipercaya sebagai dasar pengambilan keputusan. Selain itu adanya kekhawatiran akan merebaknya skandal keuangan, dapat mengikis kepercayaan publik terhadap laporan keuangan audit dan profesi akuntan publik. Seorang auditor dalam memberikan pendapat terhadap kewajaran laporan keuangan klien yang diauditnya, harus mempunyai kompetensi yang tinggi dan harus bersikap independensi terhadap tujuan kepentingan klien dan para pemakai laporan keuangan. Bebrapa penelitian menyebutkan bahwa kualitas audit sangat bergantung kepada kompetensi dan independensi auditor.

Oleh karena itu, auditor dituntut untuk dapat mempertahankan kepercayaan yang telah mereka dapatkan dari klien dan pihak ketiga yaitu dengan cara memiliki kompetensi yang tinggi dan mempertahankan independensinya dalam menghasilkan kualitas audit yang bermutu (Christiawan 2003).

Namun akhir-akhir ini profesi akuntan publik mulai dipertanyakan kredibilitasnya oleh masyarakat. Ketidakpercayaan masyarakat ini timbul dikarenakan terjadi banyak skandal yang melibatkan akuntan publik. Dari penjelasan diatas penulis mengambil fenomena yang dapat mendukung penelitian ini yaitu mengenai kasus Kantor akuntan publik mitra Ernst \& Young's (EY) di Indonesia, yakni KAP Purwantono, Suherman \& Surja sepakat membayar denda senilai US\$ 1 juta (sekitar Rp 13,3 miliar) kepada regulator Amerika Serikat, akibat divonis gagal melalukan audit laporan keuangan kliennya.

Muhammad Awal Ramadhan 66 | 84 
Begitu pula dengan kasus Kantor Akuntan Publik (KAP) Satrio Bing, Eny \& Rekan (Deloitte Indonesia). Kementerian Keuangan Republik Indonesia menjatuhkan sanksi administratif kepada masing-masing Akuntan Publik Marlinna, Akuntan Publik Merliyana Syamsul, dan Kantor Akuntan Publik (KAP) Satrio Bing, Eny \& Rekan (Deloitte Indonesia). Sanksi ini diberlakukan sehubungan dengan pengaduan Otoritas Jasa Keuangan (OJK) yang menginformasikan adanya pelanggaran prosedur audit oleh KAP. Kualitas audit dipengaruhi oleh beberapa faktor, seperti pada penelitian Winda Kurnia (2014) Pengaruh Kompetensi, Independensi, Tekanan Waktu, Dan Etika Auditor Terhadap Kualitas Audit. Penelitian yang dilakukan oleh Ade Wisteri Sawitri Nandari (2015) Pengaruh Sikap Skeptis, Independensi, Peranan Kode Etik, Dan Akuntabiltas Terhadap Kualitas Audit. Kemudian Penelitian yang dilakukan Law, Elyzabet, Santy Setiawan (2012) yaitu Pengaruh Kompetensi dan Independensi Auditor Terhadap Kualitas Audit. Dari beberapa faktor tersebut, penulis hanya mengambil faktor kompetensi dan independensi.

Terkait dengan konteks inilah, muncul pertanyaan seberapa tinggi tingkat kompetensi dan independensi auditor saat ini dan apakah kompetensi dan independensi auditor tersebut berpengaruh terhadap kualitas audit yang dihasilkan oleh akuntan publik. Kompetensi auditor dapat dibentuk diantaranya melalui pengetahuan dan pengalaman, namun sesuai dengan tanggungjawabnya untuk menaikan tingkat keandalan laporan keuangan suatu perusahaan maka akuntan publik tidak hanya perlu memiliki kompetensi atau keahlian saja tetapi juga harus independen dalam pengauditan. Independensi ini menyatakan bahwa auditor diharuskan untuk tidak mudah dipengaruhi, karena audit dilakukan atas dasar kepentingan umum, bukan kepentingan perorangan, kelompok atau golongan. Auditor diharapkan jujur dan terbuka dalam menjalankan praktik audit, ketika auditr menemukan adanya hal yang tidak wajar atau kesalahan, maka auditor wajib mengungkapkannya kepada publik.

Hal inilah yang menarik untuk diperhatikan bahwa profesi akuntan publik ibarat bermata dua. Disatu sisi auditor harus memperhatikan kredibilitas dan etika profesi, namun disisi lain auditor juga harus menghadapi tekanan dari klien dalam berbagai pengambilan keputusan. Jika auditor tidak mampu menolak penekanan dari klien seperti tekanan personal, emosional atau keuangan maka independensi auditor telah berkurang dan dapat mempengaruhi kualitas audit.

Menurut Tunggal (2013:429) kompetensi adalah pengetahuan dan keahlian yang diperlukan untuk mencapai tugas yang menentukan pekerjaan individual. Maksud dari pernyataan 
tersebut bahwa dalam pelaksanaan audit dan penyusunan laporan auditor wajib mengguanakan kemahiran profesionalitasnya dengan cermat secara individual dan objektif.

Walaupun seorang auditor memiliki keahlian tinggi tetapi dia tidak independen maka penggua laporan keuangan tidak yakin bahwa informasi yang disajikan itu kredibel. Independensi sangat diperlukan oleh akuntan publik untuk memperoleh kepercayaan dari klien dan masyarakat khususnya para pemakai laporan keuangan. Melakukan penelitian tentang kompetensi dan independensi auditor terhadap kualitas audit. Hasil penelitian menunjukan bahwa pengalaman, pengetahuan auditor, dan tekanan dari rekan auditor berpengaruh positif terhadap kualitas audit. Sedangkan lama hubungan dengan klien dan tekanan dari klien berpengaruh negatif terhadap kualitas audit. Indah (2010) dalam Tjun Tjun (2012).

Penelitian ini merupakan replikasi dari penelitian yang dilakukan oleh Lauw Tjun Tjun, Elyzabet Indrawati, dan Santy Setiawan (2012) yang berjudul "pengaruh independensi dan kompetensi terhadap kualitas auditor”. Perbedaan dengan penelitian terdahulu mengambil populasi KAP di Jakarta Pusat sedangkan penelitian ini mengambil populasi KAP di Makassar. Berdasarakan uraian diatas kiranya penting untuk diadakan penelitian, maka penulis tertarik untuk mengambil judul "Pengaruh Kompetensi Dan Independensi Auditor Terhadap Kualitas Audit”

\section{TINJAUAN PUSTAKA}

\section{Kompetensi Audit Eksternal}

Menurut Agoes (2013:146) mendefinisikan kompetensi ialah suatu kecakapan dan kemampuan dalam menjalankan suatu pekerjaan atau profesinya. Orang yang kompeten berarti orang yang dapat menjalankan pekerjaannya dengan kualitas hasil yang baik. Dalam arti luas kompetensi mencakup penguasaan ilmu/ pengetahuan (Knowledge), dan keterampilan (skill) yang mencakupi, serta mempunyai sikap dan perilaku (attitude) yang sesuai untuk melaksanakan pekerjaan atau profesinya.

Menurut Suhayati (2010:2) mendefinisikan kompetensi adalah suatu kemampuan, keahlian (pendidikan dan pelatihan), dan perpengalaman dalam memahami kriteria dan dalam menentukan jumlah bahan bukti yang dibutuhkan untuk dapat mendukung kesimpulan yang akan diambilnya.

Menurut Arens et. All (2013:42) mendefenisikan kompetensi sebagai keharusan bagi auditor untuk memiliki pendidikan formal dibanding auditing dan akuntansi, pengalaman praktik 
yang memadai bagi pekerjaan yang sedang dilakukan, serta mengikuti pendidikan professional yang berkelanjutan.

Menurut Spencer and spenser dalam Wibowo (2010:325) menyatakan bahwa kompetensi merupakan landasan dasar karakteristik orang dan mengindikasi cara berprilaku atau berfikir, menyamakan situasi dan mendukung untuk periode waktu cukup lama.

Menurut Mc Acshan dalam Sutrisno (2010:203) memberikan pengertian kompetensi adalah pengetahuan, keterampilan, dan kemampuan yang dikuasai oleh seseorang yang telah menjadi bagian dari dirinya, sehingga ia dapat melakukan perilaku-perilaku kognitif, efektif, dan psikomotorik dengan sebaik- baiknya.

Menurut De Angelo (1981) dalam Tjun Tjun (2012) dapat dilihat dari berbagai sudut pandang yakni: (a) Sudut pandang auditor individual, (b) Sudut pandang audit tim, (c) Sudut pandang Kantor Akuntan Publik (KAP).

Menurut Rai (2010: 63) terdapat 3 macam komponen kompetensi auditor yaitu: a) Mutu Personal; Dalam menjalankan tugasnya, seorang auditor harus memiliki mutu personal yang baik, seperti: (a) Rasa ingin tahu (inquisitive), (b) Berpikir luas (broad minded), (c) Mampu menangani ketidak pastian, (d) Mampu menerima bahwa tidak ada solusi yang mudah, (e) Menyadari bahwa beberapa temuan dapat bersifat subjektif, (f) Mampu bekerja sama dengan tim, b) Pengetahuan Umum; Seorang auditor harus memiliki pengetahuan umum untuk memahami entitas yang akan diaudit dan membantu pelaksanaan audit. Pengetahuan dasar ini meliputi kemampuan untuk melakukan review analisis (analiytical review), pengetahuan teori organisasi untuk memahami suatu organisasi, pengetahuan auditing, dan pengetahuan tentang sektor publik. Pengetahuan akuntansi mungkin akan membantu dalam mengolah angka dan data, namun karena audit kinerja tidak memfokuskan pada laporan keuangan maka pengetahuan akintansi bukanlah syarat utama dalam melakukan audit kinerja, c) Keahlian Khusus; Keahlian khusus yang harus dimiliki antara lain keahlian untuk melakukan wawancara, kemampuan membaca cepat, statistik, keterampilan menggunakan computer (minimal mampu mengoprasikan word processing dan spread sheet). Serta mampu menulis dan mempresentasikan laporan dengan baik.

Ada empat karakteristik kompetensi menurut Lyle dan Spencer dalam Prihadi (2004:92) yaitu sebagai berikut: (a) Motif (Motives) adalah hal-hal yang berfikir oleh seseorang untuk berfikir dan memiliki keringanan secara konsisten yang akan dapat menimbulkan tindakan. (b) 
Karakteristik (Trains) adalah fisik-fisik dan respon-respon yang konsisten terhadap situasi dan informasi. Pengetahuan (Knowledge) Pengetahuan adalah informasi yang dimiliki seseorang dalam bidang-bidang tertentu. (d) Keterampilan (Skill) Adalah kemampuan untuk melakukan tugas fisik atau mental.

Menurut Amstrong dan Murlis dalam Ramelan (2008:56), kompetensi itu ada dua yaitu kompetensi inti dan kompetensi generik atau kompetensi khusus. Kompetensi inti adalah halhal yang harus dilakukan organisasi dan orang yang ada didalamnya agar bisa berhasil. Kompetensi inti ini merupakan hasil dari pembelajaran kolektif dalam organisasi. Mereka mengatakan bahwa kompetensi inti adalah komunikasi, keterlibatan dan komitmen mendalam untuk bekerja dalam organisasi. Sedangkan kompetensi generik adalah kompetensi yang berlaku untuk kategori karyawan tertentu, seperti manajer, pemimpin tim, teknisi desain, manajer cabang, spesialis kepersonaliaan, akuntan, ooperator mesin, asisten penjualan atau sekretaris, sebagai contoh, kompetensi generik manajer cabang bisa mencakup kepemimpinan, perencanaan dan pengorganisasian., pengembangan bisnis, hubungan pelanggan, keputusan komersial, keterampilan komunikasi dan hubungan antar pribadi.kompetensi generik bisa ditetapkan untuk kelompok jabatan yang secara fundamental sifat-sifat tugasnya sama, tetapi level pekerjaan yang ditangani berbeda-beda.

\section{Independensi Audit eksternal}

Menurut Suhayati (2010:3) mendefinisikan independensi yaitu sikap yang tidak memihak kepada kepentingan siapapun. Informasi yang digunakan untuk mengambil keputusan harus tidak biasa sehingga independensi merupakan tujuan yang harus selalu diupayakan.

Menurut Randal J. Elder, Mark S. Beasley, Alvin A. Arens yang dialih bahasakan oleh Jusuf (2012:74) pengertian independensi adalah audit berarti mengambil sudut pandang yang tidak bias dalam melakukan pengujian audit, evaluasi atas hasil pengujian dan penerbitan laporan audit.

Menurut Mautz dan Sharaf dalam Tuanakotta (2011:64) menyatakan bahwa independensi mencerminkan sikap tidak memihak serta tidak dibawah pengaruh atau tekanan pihak tertentu dalam mengambil tindakan dan keputusan.

Menurut Sunyoto (2014:30) menyatakan bahwa independensi sebagai berikut. Auditor independen adalah auditor professional yang menyediakan jasanya kepada masyarakat umum, terutama dalam bidang audit atas laporan keuangan yang dibuat oleh kliennya. 
Jenis-jenis independensi menurut R.K. Mautz dan Sharaf dalam Tuanakotta (2011:64) yaitu (a) Independensi Penyusunan Program (Programming Independence), Kebebasan auditor dalam mengontrol pemilihan teknik audit dan prosedur dan memperpanjang aplikasi para auditor mempunyai wewenang untuk menyusun dan memilih teknik audit serta prosedur dan lamanya proses audit sesuai kebutuhan proses pemeriksaan yang akan dilakukan auditor sebelumnya; (b) Independensi Investigasi (Investigative Independence), Kebebasan auditor dalam mengontrol dalam memilih area, aktivitas, hubungan personal dan kebijakan manajemen untuk menjadi bahan pemeriksanya. Auditor mempunyai wewenang dan kerahasiaan untuk memilih dimana ia akan melakukan proses audit tanpa tekanan dari pihak luar guna mendapatkan bahan yang diperlukan auditor dalam proses pemeriksaan klien; (c) Independensi Pelaporan (Reporting Independence), Kebebasan auditor mengontrol dalam menyampaikan statement sesuai dengan hasil pemeriksaannya dan mengekspresikannya dalam rekomendasi atau opini sebagai hasil dari pemeriksaan auditor. Auditor mempunyai kebebasan dan wewenang tanpa intervensi dalam menyampaikan opini audit, hasil pelaporan akan disajikan sebagaimana hasil audit yang telah dilakukan auditor.

\section{Kualitas Audit Eksternal}

Menurut Halim (2008:59) mendefinisikan kualitas audit adalah laporan keuangan yang berguna bagi pembuatan keputusan adalah laporan keuangan yang berkualitas. Oleh sebab itu, kualitas audit merupakan hal yang sangat penting untuk dihasilkan oleh auditor dalam melakukan pengauditan.

Menurut Boyton, et al (2006:7) kualitas audit sangat penting untuk menghasilkan bahwa profesi bertanggung jawab kepada klien, masyarakat umum dan aturan-aturan. Kualitas audit mengacu pada standar yang berkenaan pada criteria atau ukuran mutu pelaksanaan serta dikaitkan dengan tujuan yang hendak dicapai dengan menggunakan prosedur yang berkaitan.

Menurut Rosnidah (2010) dalam Restu (2013) mendefinisikan kualitas audit adalah pelaksanaan audit yang dilakukan sesuai dengan standar sehingga mampu mengungkapkan dan melaporkan apabila terjadi pelanggaran yang dilakukan klien. Kualitas audit menurut Standar Profesional Akuntan Publik (SPAP) menyatakan bahwa audit yang dilakukan auditor dikatakan berkualitas, jika memenuhi standar auditing dan standar pengendalian mutu.

Kualitas audit diukur berdasarkan standar professional akuntan publik (SPAP) 2011:150.7 diantaranya: (a) Standar umum: Auditing dilaksanankan oleh seorang atau lebih yang 
memiliki keahlian dan pelatihan tenis yang cukup sebagai auditor, dalam semua hal yang berhubungan dengan perikatan, independensi dalam sikap mental dipertahankan oleh auditor, dalam pelaksanaan audit dan penyusunan laporannya, auditor wajib menggunakan kemahiran profesionalnya dengan cermat dan seksama; (b) Standar pekerjaan lapangan: Melakukan rencana pekerjaan sebaik-baiknya, suvervisi asisten dengan semestinya, memahami pengendalian intern untuk merencanakan audit menentukan sifat, saat dan lingkungan pengujian yang akan dilakukan, bukti audit kompeten yang cukup untuk menyatakan pendapat atas keuangan yang di audit; (c) Standar pelaporan: Kesesuaian dengan SPAP, kepatuhan terhadap SOP, pengungkapan informatif dalam laporan keuangan, tidak diperkenakan mengungkap rahasia klien.

Ikatan Akuntansi Indonesia (IAI) menyatakan bahwa audit yang dilakukan auditor dikatakan berkualitas, jika memenuhi standar auditing dan standar pengendalian mutu. Langkah-langkah yang dapat dilakukan untuk meningkatkan kualitas audit adalah: (a) Meningkatkan pendidikan profesionalnya, (b) Mempertahankan sikap independensi dalan sikap mental, (c) Dalam melaksanakan pekerjaan audit, menggunakan kemahiran profesionalnya dengan cermat dan seksama,

Melakukan perencanaan pekerjaan audit dengan baik, (e) Memahami struktur pengendalian intern klien dengan baik, (f) Memperoleh bukti audit yang cukup dan kompeten, (g) Membuat laporan audit yang sesuai dengan kondisi klien atau sesuai dengan hasil temuan.

Berdasarkan hasil penelitian yang dilakukan oleh Desis dan Giroux (1992) dalam Alim, et al (2007) mengatakan bahwa kualitas audit dipengaruhi oleh: (a) Tenure, Lama waktu auditor telah melakukan pemeriksaan terhadap suatu perusahaan, semakin lama seorang auditor telah melakukan audit pada klien yang sama maka kualitas audit yang dihasilkan semakin rendah; (b) Jumlah klien, Semakin banyak jumlah klien maka kualitas audit akan semakin baik, karena auditor dengan jumlah klien yang banyak akan berusaha menjaaga reputasinya; (c) Kesehatan keuangan klien, Semakin sehat komdisi keuangan klien maka akan ada kecenderungan klien tersebut untuk menekan auditor agar tidak mengikuti standar; (d) Review oleh pihak ketiga, Kualitas audit akan meningkat jika auditor tersebut mengetahu bahwa hasil pekerjaannya akan direview oleh pihak ketiga. Jadi, semakin besar dan semankin banyak perusahaan yang diaudit maka auditor akan semakin menjaga reputasi dan kualitas auditnya, namun kualitas audit dapat menurun seiring dengan audit tenure yang panjang. 


\section{METODE PENELITIAN}

\section{Jenis dan Sumber Data}

Dalam penulisan ini jenis data yang digunakan adalah data primer. Data primer dapat berupa opini subjek (orang) secara individual atau kelompok tentang variabel- variabel yang berkaitan dengan penelitian, seperti kompetensi dan independensi auditor. Dalam penelitian ini, data primer diperoleh melalui kuesioner yang diberikan kepada responden yakni auditor yang bekerja di kantor Akuntan Publik di Kota Makassar.

\section{Populasi dan Sampel}

Sugiyono (2012:80) mengemukakan bahwa populasi merupakan wilayah generalisasi yang terdiri atas obyek/subyek yang mempunyai kualitas dan karakteristik tertentu yang ditetapkan oleh peneliti untuk dipelajari dan kemudian ditarik kesimpulannya. Adapun populasi dalam penelitian ini meliputi seluruh auditor yang bekerja di Kantor Akuntan Publik di Kota Makassar sebanyak 37 auditor.

Sampel dalam penelitian ini adalah auditor yang menjawab kuesioner yang disebar peneliti di kantor akuntan Publik di Kota Makassar. Metode pemilihan sampel dalam penelitian ini adalah metode sampling jenuh atau sensus dimana semua anggota populasi dijadikan sampel karena pengambilan sampel relatif kecil.

\section{Metode Analisis Data}

Metode analisis yang digunakan dalam penelitian ini adalah metode Partial Least Square (PLS) dengan menggunakan software Smart PLS versi 3.2.8. Alasan digunakan PLS dalam penelitian ini adalah karena PLS dapat menganalisis dan menguji hubungan di antara variabel. Wold (1985) dalam Ghozali (2006) menyebutkan bahwa PLS merupakan metode analisis yang powerfull karena tidak didasarkan banyak asumsi, data tidak harus berdistribusi normal, dan sampel tidak harus besar. PLS terdiri dari dua pengujian, yaitu pengujian model pengukuran (outer model) dan model struktural (inner model). Dalam penelitian ini peneliti menggunakan kedua model pengujian tersebut.

\section{Deskripsi Statistik}

Perhitungan tingkat pengembalian kuisoner dapat dilihat pada tabel 3.1 sebagai berikut. 
Tabel 3.1 Ikhtisar Pengembalian Kuesioner

\begin{tabular}{|c|c|c|c|}
\hline No & Responden & $\begin{array}{l}\text { Kuesioner } \\
\text { dibagikan }\end{array}$ & $\begin{array}{c}\text { Kuesioner } \\
\text { kembali }\end{array}$ \\
\hline $\mathbf{1}$ & KAP Drs. Usman \& Rekan (Cab) & 8 & 8 \\
\hline 2 & KAP Drs. Harly Weku & 7 & 7 \\
\hline 3 & KAP Mansyur Sain \& Rekan & 7 & 6 \\
\hline 4 & KAP Drs. Rusman Thoeng & 7 & 7 \\
\hline 5 & $\begin{array}{l}\text { KAP Drs.Thomas, Blasius, Widartoyo } \\
\text { \& Rekan (Cab) }\end{array}$ & 8 & 7 \\
\hline \multicolumn{2}{|c|}{ Jumlah } & 37 & 35 \\
\hline
\end{tabular}

Berdasarkan tabel 3.1 di atas, memperlihatkan bahwa dari 37 kuesioner yang dibagikan KAP Drs. Usman \& Rekan (Cab) sebanyak 8 kuesioner dan kembali 8, KAP Drs. Harly Weku sebanyak 7 kuesioner yang kembali 7 kuesioner, KAP Mansyur Sain \& Rekan sebanyak 7 kuesioner yang kembali 6 kuesioner, KAP Drs. Rusman Thoeng sebanyak 7 kuesioner yang kembali 7 kuesioner, KAP Drs.Thomas, Blasius, Widartoyo \& Rekan (Cab) sebanyak 8 kuesioner yang kembali 7 kuesioner. Jadi jumlah kuesioner yang kembali sebanyak 35 kuesioner. Apabila dipresentasekan tingkat pengembalian kuesioner adalah sebesar 94,59\%.

Penyebaran sebanyak 37 kuesioner dilakukan mulai bulan Juni sampai Juli 2019 sebanyak 35 kuesioner yang kembali seluruhnya dapat diolah. Penelitian ini bertujuan untuk mengetahui Pengaruh Kompetensi dan Independensi Auditor terhadap Kualitas Audit (Studi Kasus Kantor Akuntan Publik di Kota Makassar).

1. Evaluasi Model Pengukuran (Outer Model)

a. Validitas Konvergen

Untuk menguji validitas konvergen digunakan nilai outer loading atau loading factor. Suatu indikator/pernyataan dinyatakan memenuhi validitas konvergen dalam kategori baik apabila nilai outer loading $>0,6$. Berikut adalah nilai outer loading dari masing-masing indikator/pernyataan pada variabel penelitian dalam tabel 4.1 sebagai berikut:

Tabel 4.1 Outer Loading

\begin{tabular}{|l|l|l|l|}
\cline { 2 - 4 } & $(\mathrm{X} 1)$ & $(\mathrm{X} 2)$ & $(\mathrm{Y})$ \\
\hline $\mathrm{X} 1.1$ & 0.819 & & \\
\hline $\mathrm{X} 1.2$ & 0.817 & & \\
\hline $\mathrm{X} 1.3$ & 0.841 & & \\
\hline $\mathrm{X} 1.4$ & 0.716 & & \\
\hline $\mathrm{X} 1.5$ & 0.729 & & \\
\hline $\mathrm{X} 1.6$ & 0.842 & & \\
\hline
\end{tabular}




\begin{tabular}{|l|l|l|l|}
\hline X1.7 & 0.717 & & \\
\hline X1.8 & 0.739 & & \\
\hline X2.1 & & 0.841 & \\
\hline X2.2 & & 0.828 & \\
\hline X2.3 & & 0.759 & \\
\hline X2.4 & & 0.762 & \\
\hline X2.5 & & 0.920 & \\
\hline X2.6 & & 0.834 & \\
\hline X2.7 & & 0.906 & \\
\hline X2.8 & & 0.783 & \\
\hline Y1 & & & 0.811 \\
\hline Y2 & & & 0.868 \\
\hline Y3 & & & 0.833 \\
\hline Y4 & & & 0.739 \\
\hline Y5 & & & 0.869 \\
\hline
\end{tabular}

Sumber : Data diolah 2019

Berdasarkan tabel 4.1 diatas memperlihatkan bahwa masing-masing indikator/pernyataan variabel penilitian telah memenuhi standar validitas konvergen yakni nilai outer loading $>0,6$. Nilai outer loading yang paling tinggi terdapat pada indikator/pernyataan X2.5 sebesar 0,920 sedangkan nilai outer loading yang paling rendah terdapat pada indikator/pernyataan X1.4 sebesar 0,716. Berikut adalah gambar 4.1 hasil nilai loading factor dari validitas konvergen:

\section{Gambar 4.1 Nilai Loading Faktor}

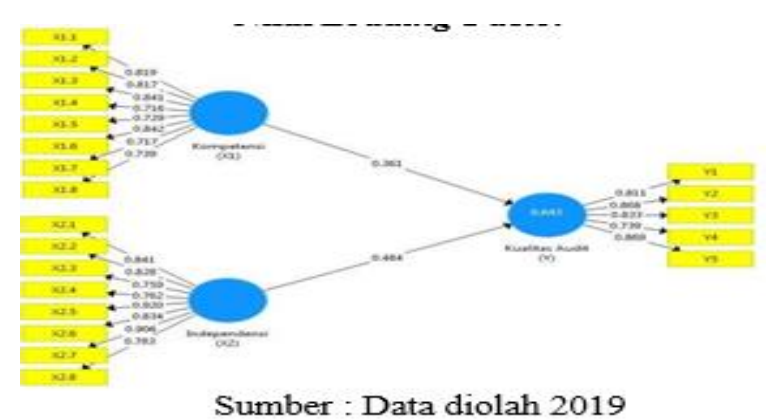

b. Validitas diskriminan

Untuk menguji validitas diskriminan menggunakan nilai cross loading. Suatu indikator/pernyataan dikatakan memenuhi validitas diskriminan apabila nilai cross loading indikator/pernyataan pada variabelnya adalah yang terbesar dibandingkan pada variabel lainnya. Berikut ini adalah nilai cross loading masing- masing indikator/pernyataan: 
Tabel 4.2 Cross Loading

\begin{tabular}{|c|c|c|c|}
\hline & (X1) & $(\times 2)$ & (Y) \\
\hline$\times 1.1$ & 0.819 & 0.755 & 0.568 \\
\hline$\times 1.2$ & 0.817 & 0.609 & 0.689 \\
\hline$\times 1.3$ & 0.841 & 0.627 & 0.620 \\
\hline$\times 1.4$ & 0.716 & 0.564 & 0.517 \\
\hline$\times 1.5$ & 0.729 & 0.766 & 0.550 \\
\hline$\times 1.6$ & 0.842 & 0.620 & 0.652 \\
\hline$\times 1.7$ & 0.717 & 0.490 & 0.531 \\
\hline$\times 1.8$ & 0.739 & 0.527 & 0.484 \\
\hline$\times 2.1$ & 0.750 & 0.841 & 0.750 \\
\hline$\times 2.2$ & 0.547 & 0.828 & 0.398 \\
\hline$\times 2.3$ & 0.498 & 0.759 & 0.398 \\
\hline$\times 2.4$ & 0.777 & 0.762 & 0.688 \\
\hline$\times 2.5$ & 0.667 & 0.920 & 0.566 \\
\hline$\times 2.6$ & 0.538 & 0.834 & 0.661 \\
\hline$\times 2.7$ & 0.643 & 0.906 & 0.682 \\
\hline$\times 2.8$ & 0.731 & 0.783 & 0.749 \\
\hline Y1 & 0.633 & 0.607 & 0.811 \\
\hline Y2 & 0.637 & 0.708 & 0.868 \\
\hline Y3 & 0.628 & 0.593 & 0.833 \\
\hline Y4 & 0.512 & 0.457 & 0.739 \\
\hline Y5 & 0.656 & 0.769 & 0.869 \\
\hline
\end{tabular}

Berdasarkan tabel 4.2 diatas, memperlihatkan bahwa masing-masing indikator/pernyataan pada variabel penelitian memiliki nilai cross loading terbesar pada variabel yang dibentuknya dibandingkan dengan nilai cross loading pada variabel lainnya. Berdasarkan hasil yang di peroleh tersebut, dapat dinyatakan bahwa indikator-indikator/pernyataan-pernyataan yang digunakan dalam penelitian ini telah memiliki validitas diskriminan yang baik dalam menyusun variabelnya masingmasing.

c. Reliabilitas Komposit

Reliabilitas komposit merupakan bagian yang digunakan untuk menguji nilai reliabilitas indikator-indikator/pernyataan-pernyataan pada suatu variabel. Suatu variabel dapat dinyatakan memenuhi reliabilitas komposit apabila memiliki nilai reliabilitas komposit>0,7. Berikut ini adalah nilai reliabilitas komposit dari masingmasing variabel yang digunakan dalam penelitian: 
Tabel 4.3 Reliabilitas Komposit

\begin{tabular}{|l|l|l|l|l|}
\cline { 2 - 5 } & $\begin{array}{l}\text { Cronba } \\
\text { ch's } \\
\text { Alpha }\end{array}$ & $\begin{array}{l}\text { rho } \\
\text { A }\end{array}$ & $\begin{array}{l}\text { Reliabili } \\
\text { tas } \\
\text { Kompo } \\
\text { sit }\end{array}$ & $\begin{array}{l}\text { Rata } \\
\text { rata } \\
\text { Varian } \\
\text { s } \\
\text { Diekst } \\
\text { rak } \\
\text { (AVE) }\end{array}$ \\
\hline $\begin{array}{l}\text { Independ } \\
\text { ensi } \\
\text { (X2) }\end{array}$ & 0.937 & $\begin{array}{l}0.94 \\
6\end{array}$ & 0.947 & 0.691 \\
\hline $\begin{array}{l}\text { Kompete } \\
\text { nsi } \\
\text { (X1) }\end{array}$ & 0.907 & $\begin{array}{l}0.91 \\
3\end{array}$ & 0.925 & 0.607 \\
\hline $\begin{array}{l}\text { Kualitas } \\
\text { Audit } \\
\text { (Y) }\end{array}$ & 0.883 & $\begin{array}{l}0.89 \\
5\end{array}$ & 0.914 & 0.681 \\
\hline
\end{tabular}

Berdasarkan tabel 4.3 diatas, memperlihatkan bahwa nilai reliabilitas komposit semua variabel penelitian $>0,7$. Hasil ini menunjukkan bahwa masing-masing variabel telah memenuhi reliabilitas komposit sehingga dapat disimpukan bahwa keseluruhan variabel memiliki tingkat reliabilitas yang tinggi.

2. Evaluasi Model Struktural (Inner Model)

a. $\mathrm{Uji} R$ Square $\left(\mathrm{R}^{2}\right)$

Berdasarkan pengolahan data yang telah di lakukan dengan menggunakan program SmartPLS3 di peroleh nilai $R$ Square sebagai berikut:

Tabel 4.4 R Square

\begin{tabular}{|l|l|l|}
\cline { 2 - 3 } & R Square & $\begin{array}{l}\text { Adjusted R } \\
\text { Square }\end{array}$ \\
\hline $\begin{array}{l}\text { Kualitas } \\
\text { Audit } \\
\text { (Y) }\end{array}$ & 0.643 & 0.621 \\
\hline
\end{tabular}

Sumber: Data diolah 2019

Berdasarkan tabel 4.4 diatas, memperlihatkan bahwa nilai $R$ square untuk variabel kualitas audit adalah 0,643. Perolehan nilai tersebut menjelaskan bahwa pengaruh kompetensi dan independensi auditor terhadap kualitas audit adalah sebesar 64,3\% dan sisanya 35,7\% di pengaruhi oleh konstruk lain di luar penelitian ini.

b. Uji Hipotesis

Berdasarkan olah data yang telah dilakukan, hasil yang dapat digunakan untuk menjawab hipotesis pada penelitian ini dilakukan dengan melihat nilai T Statistics dan $P$ Values. Hipotesis penelitian dinyatakan diterima apabila $P$ Values $<0,05$. Berikut adalah hasil uji hipotesis yang diperoleh dalam penelitian ini melalui inner 
model:

Tabel 4.5 Mean, STDEV, T-Values, P-Values

\begin{tabular}{|c|c|c|c|c|c|}
\hline & $\begin{array}{l}\text { Sam } \\
\text { pel } \\
\text { Asli } \\
\text { (O) }\end{array}$ & $\begin{array}{l}\text { Rata- } \\
\text { rata } \\
\text { Sam } \\
\text { pel } \\
\text { (M) }\end{array}$ & $\begin{array}{l}\text { Stand } \\
\text { ar } \\
\text { Devia } \\
\text { si } \\
\text { (STD } \\
\text { EV) }\end{array}$ & $\begin{array}{l}\text { T } \\
\text { Statist } \\
\text { ik (I } \\
\text { O/STD } \\
\text { EV I) }\end{array}$ & $\begin{array}{l}\text { P } \\
\text { Valu } \\
\text { es }\end{array}$ \\
\hline \multicolumn{6}{|l|}{ Kompetensi_ } \\
\hline $\begin{array}{l}\text { (X1) } \\
\text { Kualitas }\end{array}$ & $\begin{array}{l}0.36 \\
1\end{array}$ & $\begin{array}{l}0.36 \\
3\end{array}$ & 0.177 & 2.036 & $\begin{array}{l}0.04 \\
2\end{array}$ \\
\hline Audit_(Y) & & & & & \\
\hline \multicolumn{6}{|l|}{ Independens } \\
\hline $\begin{array}{l}\text { i_(X2) } \\
\text { Kualitas }\end{array}$ & $\begin{array}{l}0.48 \\
4\end{array}$ & $\begin{array}{l}0.50 \\
2\end{array}$ & 0.141 & 3.432 & $\begin{array}{l}0.00 \\
1\end{array}$ \\
\hline Audit_(Y) & & & & & \\
\hline
\end{tabular}

Berdasarkan tabel 4.5 diatas, memperihatkan bahwa dari dua hipotesis yang diajukan dalam penelitian ini tidak semuanya dapat diterima karena masing-masing pengaruh yang ditunjukkan yaitu:

1) Variabel Kompetensi (X1) berpengaruh terhadap kualitas audit (Y) dengan nilai T Statistik sebesar 2,036 > T Tabel sebesar 1,694 sedangkan $P$ Values sebesar $0,042>0,05$. Jadi dapat dinyatakan bahwa pengaruh kompetensi auditor terhadap kualitas audit terbukti atau diterima.

2) Variabel Independensi (X2) berpengaruh terhadap kualitas audit (Y) dengan nilai T Statistik sebesar 3,432 > T Tabel sebesar 1,694 sedangkan $P$ Values sebesar 0,001 >0,05. Jadi dapat dinyatakan bahwa pengaruh independensi auditor terhadap kualitas audit terbukti atau diterima. Berikut adalah gambar 4.2 hasil nilai output bootstrapping dari uji hipotesis.

Gambar 4.2 Output Bootstrapping

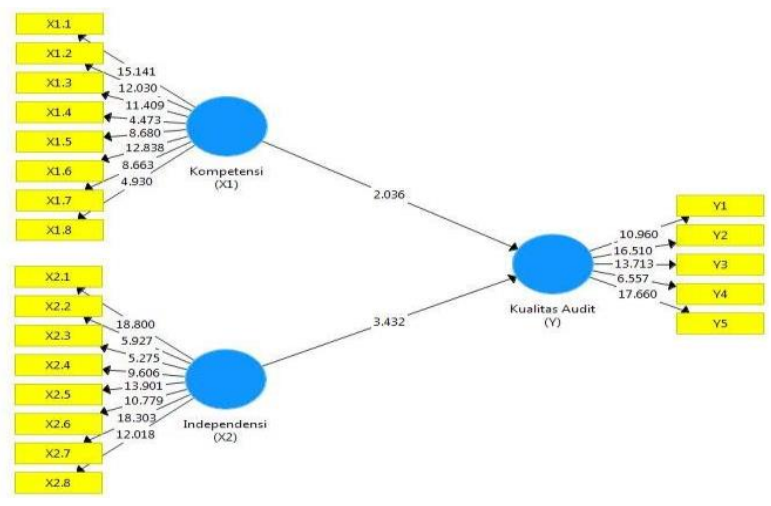

Sumber: Data diolah 2019 


\section{HASIL DAN PEMBAHASAN}

1. Pengaruh Kompetensi Auditor (X1) terhadap Kualitas Audit (Y)

Dari penelitian ini diketahui bahwa Kompetensi berpengaruh terhadap Kualitas Audit pada Kantor Akuntan Publik di kota Makassar dengan nilai TStatistik sebesar 2,036 > TTabel sebesar 1.694 sedangkan PValues sebesar $0,042<0.05$. Kondisi ini menggambarkan bahwa semakin tinggi atau rendah kompetensi yang dimiliki seorang auditor maka akan berpengaruh terhadap kualitas audit pada lembaga tersebut.

Menurut Rai (2010 : 63) yang menyatakan bahwa ada tiga komponen kompetensi auditor, yaitu mutu personal yang baik, pengetahuan umum, dan juga keahlian khusus. Oleh karena itu dibutuhkan sumber daya manusia yang memiliki kompetensi yang baik dalam melaksanakan pengauditan agar menghasilkan hasil audit yang berkualitas.

Penelitian ini menunjukan hasil bahwa terdapat pengaruh yang signifikan antara variabel kompetensi auditor terhadap kualitas audit. Kompetensi auditor merupakan salah satu yang harus dimiliki oleh seorang auditor, karena kompetensi erat kaitannya dengan kualitas audit. Dengan adanya kompetensi maka auditor dirasa memiliki pengetahuan dan pengalaman serta keahlian khusus yang cukup mengenai bidang audit. Pengetahuan yang sudah dimiliki harus digali lebih banyak lagi sehingga dapat memudahkan auditor dalam memecahkan permasalahan yang dihadapi saat melaksanakan proses audit dan dapat mengikuti perkembangan yang terjadi saat ini. Pengalaman yang pernah didapat sebelumnya harus dituangkan kembali saat melakukan proses audit, sehingga dalam menyelesaikan proses audit akan lebih baik dan lebih cepat karena sudah pempunyai pengalaman sebelumnya. Dengan pengetahuan dan pengalaman dalam bidang audit, maka auditor akan dapat menyelesaikan auditnya dengan baik sehingga mampu menghasilkan kualitas audit yang baik dan memadai.

Hasil penelitian ini didukung oleh beberapa hasil penelitian terdahulu seperti Tjun (2012), Kurnia (2014), Alim (2007), Ilmayati (2012), Suraida (2005), Suriah (2009), Agusti(2013), Ningsih (2013), Septriani (2012), dan Ardini (2010) yang menyatakan bahwa kompetensi auditor berpengaruh signifikan terhadap kualitas audit. Hal ini semakin menunjukkan bahwa semakin tinggi kompetensi seorang auditor maka semakin tinggi pula kualitas audit yang dihasilkan. Dengan demikian dapat disimpulkan hipotesis yang menyatakan bahwa Kompetensi berpengaruh terhadap kualitas audit pada 
Kantor Akuntan Publik di kota Makassar dinyatakan diterima.

2. Pengaruh Independensi Auditor (X2) terhadap Kualitas Audit (Y)

Dari penelitian ini diketahui bahwa Independensi berpengaruh terhadap Kualitas Audit pada Kantor Akuntan Publik di kota Makassar dengan nilai TStatistik sebesar 3,432 TTabel sebesar 1.694 sedangkan PValues sebesar $0,001<0.05$. Kondisi ini menggambarkan bahwa semakin kuat Independensi yang dimiliki seorang auditor maka akan berpengaruh terhadap kualitas audit pada lembaga tersebut.Menurut Mautz dan Sharaf dalam Tuanakotta (2011:64) yang menyatakan bahwa independensi mencerminkan sikap tidak memihak serta tidak dibawah pengaruh atau tekanan pihak tertentu dalam mengambil tindakan dan keputusan. Oleh karena itu, untuk menghasilkan audit yang berkualitas diperlukan sikap independen dari auditor. Karena jika auditor kehilangan independensinya maka laporan audit yang dihasilkan tidak sesuai dengan kenyataan yang ada sehingga tidak dapat digunakan sebagai dasar pengambilan keputusan. Kemudian dengan sikap independensinya maka auditor dapat melaporkan dalam laporan auditan jika terjadi pelanggaran dalam laporan keuangan kliennya

Hasil penelitian didukung oleh beberapa penelitian terdahulu seperti penelitian Kurnia (2014), Christiawan (2002), Singgih (2010), Wiratama (2015), Agusti (2013), Ningsih (2013), Pratishta (2014), Septriani (2012), dan Ardini (2010) yang menyatakan bahwa independensi auditor berpengaruh signifikan terhadap kualitas audit. Hal ini semakin menunjukkan bahwa semakin tinggiindependensi seorang auditor maka semakin tinggi pula kualitas audit yang dihasilkan.

Namun, hasil penelitian ini juga bertolak belakang dengan beberapa penelitian terdahulu seperti penelitian yang dilakukan oleh Tjun (2012), Nandari (2015), Alim (2007), Suriah (2009) yang menyatakan bahwa independensi tidak berpengaruh signifikan terhadap kualitas audit. Hal ini menunjukkan bahwa adanya indikator-indikator yang mungkin tidak sejalan dengan penelitian ini sehingga bertolak belakang dengan beberapa penelitian terdahulu.

Akan tetapi, dengan adanya sikap independensi tinggi yang dimiliki oleh auditor, maka auditor dalam melakukan proses audit, auditor akan bersikap objektif dalam memeriksa tanpa memandang siapapun subjek atau klien yang sedang diaudit. Sikap independensi diperlukan oleh seorang auditor, agar dalam memeriksa juga auditor tidak dibatasi ruang 
lingkupnya, sehingga auditor.

Dengan demikian dapat disimpulkan hipotesis yang menyatakan bahwa Independensi berpengaruh terhadap kualitas audit pada Kantor Akuntan Publik di kota Makassar dinyatakan diterima.

\section{PENUTUP}

\section{Simpulan}

Penelitian ini bertujuan untuk menganalisis dan mengetahui pengaruh kompetensi dan independensi auditor terhadap kualitas audit. Dalam penelitian ini menggunakan alat analisis regresi linier berganda dengan menggunakan instrument SmartPLS versi 3.2.8.

Berdasarkan analisis pembahasan diatas pada bab sebelumnya, maka kesimpulannya sebagai berikut:

1. Kompetensi berpengaruh terhadap Kualitas Audit pada Kantor Akuntan Publik di kota Makassar dengan nilai TStatistik sebesar 2,036 > TTabel sebesar 1.694 sedangkan PValues sebesar 0,042 $<0.05$. Kondisi ini menggambarkan bahwa semakin tinggi atau rendah kompetensi yang dimiliki seorang auditor maka akan berpengaruh terhadap kualitas audit pada lembaga tersebut.

2. Independensi berpengaruh terhadap Kualitas Audit pada Kantor Akuntan Publik di kota Makassar dengan nilai TStatistik sebesar 3,432 TTabel sebesar 1.694 sedangkan PValues sebesar $0,001<0.05$. Kondisi ini menggambarkan bahwa semakin kuat Independensi yang dimiliki seorang auditor maka akan berpengaruh terhadap kualitas audit pada lembaga tersebut.

Berdasarkan nilai $R$ Square untuk variabel kualitas audit adalah 0,643 . Perolehan nilai tersebut menjelaskan bahwa pengaruh Kompetensi dan Independensi auditor terhadap Kualitas Audit adalah sebesar 64,3\% dan sisanya 35,7\% dipengaruh oleh konstruk lain di luar dari penelitian ini.

\section{Saran}

Berikut adalah beberapa saran peneliti berikan kepada pembaca yaitu sebagai berikut:

1. Diharapkan penelitian ini dapat digunakan sebagai sumber referensi penelitian selanjutnya yang memiliki topik dan tema yang sama. 
2. Peneliti juga menyarankan jangan membatasi pengambilan sampel hanya bebarapa daerah saja, semakin luas lingkup pengambilan sampel yang digunakan akan semakin dapat dipercaya hasil penelitian yang dihasilkan.

3. Peneliti menyarankan pula untuk tidak mendasarkan pengukuran variabel penelitian pada persepsi responden saja.

4. Pengumpulan data pada penelitian selanjutnya diharapkan tidak hanya sebatas penyebaran kuesioner saja tetapi dapat juga dilakukan dengan pengamatan, dokumentasi, observasi serta wawancara langsung ke objek penelitian. Kehadiran peneliti pada saat responden melakukan pengisian kuesioner sebaiknya dilakukan, karena responden dapat menanyakan secara langsung butir-butir pernyataan yang tidak dipahami.

\section{DAFTAR PUSTAKA}

Agoes, Sukrisno. Ardana, Cenik. 2013, Etika Bisnis dan Profesi Tantangan Membangun manusia seutuhnya. Jakarta: Salemba Empat.

Abdul Halim, Sutrisno T, Rosidi, M. Achsin. 2014. "Effect of Competence and Independence on Audit Quality with Audit Audit Time Budget and Professional Commitment as a Moderation Variable".

Al, Haryono, Jusup, 2001. AUDITING edisi pertama. Yogyakarta: Sekolah Tinggi Ilmu Ekonimi YKPN.

Agusti Restu \& Nastia Putri Pertiwi., 2013, Pengaruh Kompetensi, Independensi dan Profesionalisme Terhadap Kualitas Audit (Studi Empiris pada Kantor Akuntan Publik Se Sumatera). Jurnal Ekonomi Vol. 21 No. 3

Alim, M.N., Hapsari, T., \& Purwati L., 2007, Pengaruh Kompetensi dan Independensi Terhadap Kualitas Audit dengan Etika Auditor Sebagai Variabel Moderasi, Simposium Nasional Akuntansi X, Makasar.

Amstrong Michael \& Murlis Helen. Reward Management. Buku satu \& dua, Terjemahan Ramelan. 2008. Jakarta: Bhuana Ilmu Populer.

Arens, Alvin.A., Randal.J. Elder, \& Mark.S. Beasley, 2008, Auditing dan Jasa Assurance, Jakarta: Erlangga.

Arens, Alvin.A., Randal.J. Elder,Amira. A.J. \& Mark.S. Beasley, 2011, Auditing dan Jasa Assurance, Jakarta: Penerbitan Salemba Empat.

Badan Pemeriksa Keuangan Republik Indonesia 2007 "Standar Pemeriksaan Keuangan Negara".

Boyton, William, dkk 2006. Modern Auditing 8th Edition. John Wiley dan Sons, Inc.

Christiawan, Yulis Jogi.2003, “Kompetensi dan Independensi Akuntan Publik: Refleksi Hasil Penelitian Empiris”. Jurnal Akuntansi dan Keuangan vol.4 No.2 
Fitrawansyah. 2014, Fraud \& Auditing. Jakarta: Mitra Wacana Media.

Ghozali, Imam. 2006. Aplikasi Analisis Multivariate Dengan Program SPSS. Cetakan Keempat. Semarang: Badan Penerbit Universitas Diponegoro.

Halim, Abdul. 2008, AUDITING: Dasar-dasar Audit Laporan Keuangan. Yogyakarta: Unit Penerbit dan Percetakan STIM YKPN.

Hery. 2010, Potret Profesi Audit Internal cetak kesatu. Bandung:Alfabeta.

Hutabarat, Goodman. 2012. Pengaruh Pengalaman Time Budget Pressure dan Etika Auditor Terhadap Kualitas Audit. Jurnal Ilmiah Esai. Vol 1,No.1.

IAI (Ikatan Akuntansi Indonesia). 2001, "Standar Profesional Akuntan Publik (SPAP)”. Jakarta: Salemba Empat.

IFAC (International Federation of Accountants). 2010, "Handbook Of the Code of Ethics for Proffessional Accountants: 2010 Edition”. New York.

Ilmayati, Fenny. Yohanes Suhardjo. 2012. Pengaruh Akuntabilitas dan Komepetensi Auditor Terhadap Kualitas Audit. JURAKSI Vol 1 No 1.

Indranata, Iskandar. 2006, Terampil dan Sukses Melakukan Audit Mutu Internal. Bandung: Alfabeta.

Kurnia, Winda. Khomsiyah. Sofie.2014, "Pengaruh Kompetensi, Independensi, Tekanan Waktu, dan Etika Auditor Terhadap Kualitas Audit”.

Mukhlasin.2004, "Pengaruh Atribut Kualitas Audit, Portofolio Jasa Audit, dan Reputasi Kantor Akuntan PublikTerhadap Keluasan Klien”. BALANCE-1

Nandari Ade Wisteri Sawitri, Made Yenni Latrini. 2015 "Pengaruh Sikap Skeptis, dan Akuntabilitas Terhadap Kualitas Audit".

Ningsih, A.A Putu Ratih Cahaya. P. Dyan Yaniartha S. 2013. Pengaruh Kompetensi, Independensi, Dan Time Budget Pressure Terhadap Kualitas Audit. E-Jurnal Universitas Udayana 4.1.

Nugraha, Mikhail Edwin. 2012. Pengaruh Independensi, Kompetensi, dan Profesionalisme terhadap Kualitas Audit. Refleksi Hasil Penelitian Empiris. Jurnal Ilmiah Mahasiswa Akuntansi. Vol 1, No.4.

Pratistha, K. Dwiyanti. Ni Luh Sari Widhiyani. Pengaruh Independensi Auditor Dan Besaran Fee Audit Terhadap Kualitas Proses Audit. E-Jurnal Universitas Udayana 6.3

Prihadi, Syaiful F., 2004. Assessment Centre: Identifikasi, pengukuran Pengembangan Kompetensi. Jakarta:Gramedia Pustaka Utama.

Rai, I Gusti agung, 2010. Auditing kinerja pada sektor publik. Jakarta:Salemba Empat

Singgih, Elisha Muliana \& Icuk Rangga Bawono. 2010, "Pengaruh Independensi, Pengalaman, Due Professional Care dan Akuntabilitas Terhadap Kualitas audit”. SNA 13.

Sugiyono. 2012. Metode Penelitian kualitatif dan kuatitaif dan R\&D. Bandung:Alfabeta

Suhayati, Ely, Siti Kurnia Rahayu.2010, AUDITING, Konsep Dasar dan Pedoman Pemeriksaan Akuntan Publik. Yogyakarta:Graha Ilmu. 
Sunyoto, Danang. 2014, AUDITING pemeriksaan akuntansi. Jakarta:PT. Buku Seru.

Suraida, Ida. 2005. Pengaruh Etika, Kompetensi, Pengalaman Audit dan Risiko Audit terhadap Skeptisisme Profesional Auditor dan Ketepatan Pemberian Opini Akuntan Publik. Sosiohumaniora Vol 7 No 3.

Suriah, Ika. Akram. Biana Adha Inapty. 2009. Pengaruh Pengalaman Kerja, Independensi, Obyektifitas, Integritas dan Kompetensi Terhadap Kualitas Hasil Pemeriksaan. SNA 12. Palembang: Universitas Sriwijaya. Sutrisno, Edy. 2010, Manajemen Sumber Daya Manusia edisi pertama. Jakarta:Kencana Prenada Media Group.

Tjun Tjun Lauw, Elyzabeth I. M., \& Santy Setiawan. 2012. "Pengaruh Kompetensi dan Independensi Terhadap Kualitas Audit”. Jurnal Akuntansi vol 4 no.1 Mei 2012. Bandung: Program Studi Akuntansi, Universitas Kristen Maranata.

Tuanakotta, Theoudorus M. 2011. Berpikir Kritis dalam Auditing. Jakarta:Salemba Empat.

Tunggal, Amin Widjaja. 2013, Dasar-dasar Fraud Auditing. Jakarta:Harvarindo.

Wahyuningsih. 2012 Pengaruh Pengalaman, Tekanan, Dan Integritas Auditor Terhadap Kualitas Audit. Skripsi. Universitas Islam Negri (UIN) Alauddin Makassar. 2012

Wibowo. 2010, Manajemen Kinerja edisi ketiga. Jakarta:Rajawali Pers.

Wiratama, William Jefferson. Ketut Budiarta. 2015 Pengaruh Independensi, Pengalaman Kerja, Due Professional Care Dan Akuntabilitas Terhadap Kualitas Audit. E- Jurnal Universitas Udayana 10.1. 